\title{
Quantification of Chlorophyll and Carotene Pigments Content in Mountain Melick (Melica nutans L.) in Relation to Edaphic Variables
}

\author{
Waldemar Zielewicz ${ }^{1}\left(\right.$, Barbara Wróbel $^{2}\left(\mathbb{D}\right.$ and Gniewko Niedbała ${ }^{3, *(1)}$ \\ 1 Department of Grassland and Natural Landscape Sciences, Faculty of Agronomy, \\ Horticulture and Bioengineering, Poznań University of Life Sciences, Dojazd 11, 60-632 Poznań, Poland; \\ waldemar.zielewicz@up.poznan.pl \\ 2 Department of Grassland Farming, Institute of Technology and Life Sciences, Falenty, Aleja Hrabska 3, \\ 05-090 Raszyn, Poland; b.wrobel@itp.edu.pl \\ 3 Department of Biosystems Engineering, Faculty of Environmental Engineering and Mechanical Engineering, \\ Poznań University of Life Sciences, Wojska Polskiego 50, 60-627 Poznań, Poland \\ * Correspondence: gniewko@up.poznan.pl
}

Received: 19 October 2020; Accepted: 11 November 2020; Published: 13 November 2020

\begin{abstract}
The aim of the study was to identify and compare the content of chlorophyll and carotene pigments in mountain melick plants (Melica nutans L.) growing in two forest habitats in the Zielonka Forest Landscape Park in the Greater Poland region, which differed in soil properties and moisture. Leaf blades from the middle level of Melica nutans generative shoots were used as analytical material to measure the content of chlorophyll $a$, chlorophyll $b, \beta$-carotene and total carotenoids. The average $( \pm$ SD) content of chlorophyll $a$ in the Melica nutans plants growing in the less fertile site (Location I) amounted to $6.67 \pm 0.99 \mathrm{mg} \cdot \mathrm{g}^{-1} \mathrm{DM}$. The average content of chlorophyll $b$ in the same plants was $2.44 \pm 0.39 \mathrm{mg} \cdot \mathrm{g}^{-1} \mathrm{DM}$. The Melica nutans plants growing in the more fertile site (Location II) had a higher content of chlorophyll $a$, i.e., $7.76 \pm 0.96 \mathrm{mg} \cdot \mathrm{g}^{-1} \mathrm{DM}$, and lower content of chlorophyll $b$, i.e., $2.36 \pm 0.26 \mathrm{mg} \cdot \mathrm{g}^{-1} \mathrm{DM}$. The plants collected from both sites had similar content of $\beta$-carotene, i.e., $0.61 \pm 0.11 \mathrm{mg} \cdot \mathrm{g}^{-1} \mathrm{DM}$ Location I and $0.62 \pm 0.07 \mathrm{mg} \cdot \mathrm{g}^{-1} \mathrm{DM}$ Location II. The plants growing in the less fertile site (Location I) had significantly higher total carotene content than the plants in the more fertile site (Location II). The content of pigments in the Melica nutans plants was significantly differentiated by the meteorological conditions in the subsequent years of the research. In the first year of the research, the average content of all chlorophyll pigments in the plants was significantly higher than in the second drier year, regardless of the site.
\end{abstract}

Keywords: forest grasses; chlorophyl; carotenoids; forest habitats; leaf blades; soil and moisture conditions

\section{Introduction}

Forest grasses are a group of plants whose biological, chemical and morphological properties have still not been fully investigated and described. Grasses perform various functions in forests-they make turf, provide forage and are an element of the landscape [1-4]. Mountain melick (Melica nutans L.) is an interesting grass species growing in forest habitats, usually in lowlands and mountains $[5,6]$. It can be found in shady deciduous forests classified as Querco-Fagetea Br.-Bl. Vlieger (1937). This plant grows well in fertile neutral and alkaline soils with moderate moisture [7]. Due to the commonness of this species in forests, it can be treated as forage grass for forest animals. The plant is also grown in home gardens as ornamental grass because it produces an interesting inflorescence [8]. Assimilation pigments such as chlorophylls and carotenes are some of the most important chemical compounds in 
plants because they affect the intensity of photosynthesis and the production of biomass. Chlorophyll plays a key role in biosynthesis processes, because it enables the conversion of light energy into the energy of chemical bonds in the photosynthetic process [9]. The chlorophyll molecule is made of pheoporphyrin, which is a porphyrin derivative. The magnesium atom, which connects to the nitrogen atoms in each ring, is in the centre of the porphyrin system. There are various types of chlorophylls. Chlorophyll $a$ and chlorophyll $b$ are the most common types occurring in nature. They can be found in green algae and all plants performing photosynthesis. The ratio of chlorophyll $a$ to chlorophyll $b$ in higher plants is about 3:1 [10]. Chlorophyll pigments determine the intensity of the plant colour. The content of pigments also affects the chemical composition of plants and is used in various statistical correlations referring to their physiology and chemistry [11,12]. The content of chlorophyll is a species-specific or even variety-specific trait [13]. Researchers have attempted to create a decreasing sequence of grass species with their individual species-specific content of chlorophyll pigments [2]. The content of chlorophyll pigments in plants is also considered an indicator of their response to the habitat, weather and anthropogenic conditions [14-17]. It can also be a reliable indicator of the vitality of plants and their resistance to stressful thermal and humidity conditions [18]. Modern indexing methods enable quick and easy measurement of the current content of chlorophyll. For this reason, research on the chlorophyll content is becoming more and more common and it can be done easily even in a field $[19,20]$. The measurement of the chlorophyll content may be an important indicator of the plant's life processes, which may affect the yield of biomass.

Apart from chlorophylls, carotenoids are another most common group of plant pigments. They can be found in all photosynthetic organisms. Carotenoids are secondary metabolites of plants, which can be divided into two groups: hydrocarbon carotenes, such as $\beta$-carotene, and xanthophylls, i.e., oxygenated derivatives of carotenes. It is a group of lipophilic compounds, whose colours range from yellow through orange to red. Carotene pigments have minimal influence on the plant colour, because they are masked by chlorophyll [21]. Carotenoids are auxiliary pigments in photosynthesis. They transfer the absorbed energy to chlorophyll with an efficiency of $15 \%-90 \%$. They also protect chlorophyll from excessive light intensity. $\beta$-carotene is a source of vitamin A for animals [22]. Kozłowski and Kukułka [23] and Olszewska [24] indicated that cultivated species and varieties of nitrophilous grasses differed considerably in their content of carotene.

Considering that the content of plant pigments is very variable and depends on many factors, it was hypothesized that the content of chlorophyll and carotene pigments in plants belonging to the same species will vary depending on the habitat conditions, including the soil fertility of the habitat and moisture conditions. The aim of the study was to check how different soil properties and moisture conditions can modify the content of chlorophyll and carotene pigments in mountain melick plants (Melica nutans L.) growing in two forest habitats. The investigation of this species in terms of the content of these pigments may help to determine its viability and nutritional value. Forest habitats are a difficult environment for grasses to grow and develop, especially due to humidity, light and the abundance of nutrients in soil.

\section{Materials and Methods}

\subsection{Research Sites}

The research was conducted in two consecutive years (2007 and 2008) differing with weather conditions during the growing season. The material for analyses of the content of selected pigments in the leaves of mountain melick plants (Melica nutans) was collected from natural forest sites located in Zielonka Forest Landscape Park in the Greater Poland region (Poland). The largest groups of this species were found in two forest habitats differing with soil and light conditions. They were: forest habitat near the villages of Bolechowo (52 $51^{\prime} 48^{\prime \prime} \mathrm{N}, 17^{\circ} 01^{\prime} 31^{\prime \prime}$ E) - Location I and forest habitat around the village of Wojnówko $\left(52^{\circ} 64^{\prime} 0^{\prime \prime} \mathrm{N}, 17^{\circ} 07^{\prime} 98^{\prime \prime} \mathrm{E}\right)$ - Location II. Twelve sites with the plants were selected in the forest habitat in Location I and sixteen sites in Location II. Plastic markers with numbers 
were placed at the sites to collect Melica nutans plant material for chemical analyses at the same places during the two years of the research.

Each year three soil samples were collected from the top layer $(0-20 \mathrm{~cm})$ at the time of plant sampling in order to characterise the soil conditions of the forest habitats in Location I and Location II. The following parameters of the samples were determined: soil $\mathrm{pH}$, the content of $\mathrm{P}_{2} \mathrm{O}_{5}, \mathrm{~K}_{2} \mathrm{O}$ (double lactate method) and $\mathrm{MgO}$ (Schachtschabel method). The soil samples were analysed at the District Chemical and Agricultural Station in Poznań.

\subsection{Collection and Analysis of Plant Material}

In July twenty leaf blades were collected from each site marked with individual numbers (1-12 in Location I and 1-16 in Location II) in order to analyse them for the content of chlorophyll and carotene pigments. The samples were collected from an area of $1 \mathrm{~m}^{2}$ of Melica nutans plant community at each site. The leaf blades were collected from the middle level of the height of generative shoots of mountain melick plants. The samples were wrapped in paper envelopes with the site number. When the mountain melick material was brought to the laboratory, it was stored in a freezer to keep it fresh until laboratory analyses. The content of chlorophyll $a$, chlorophyll $b, \beta$-carotene and total carotenoids in the plant material was measured. The content of chlorophyll pigments was measured by means of spectrophotometry, according to the procedure described by Smith and Benitez [25]. The plant material was macerated in a ceramic mortar with sand and anhydrous sodium carbonate $\left(\mathrm{Na}_{2} \mathrm{CO}_{3}\right)$ and then chlorophyll pigments were extracted with $85 \%$ acetone. The content of carotene pigments was measured with the method described by Berger [26]. The plant material was macerated in a ceramic mortar with sand and then the carotene pigments were extracted with petroleum ether (boiling point $40-60^{\circ} \mathrm{C}$ ) and alcohol $(45 \%)$, to which sodium hydroxide $(\mathrm{NaOH})$ was added. Extinction was read with a Marcel Media spectrophotometer (Marcel Sp.z o.o., Warsaw, Poland)—chlorophyll $a$ at a wavelength of $642.5 \mu \mathrm{m}$, chlorophyll $b$ at a wavelength of $660 \mu \mathrm{m}$. The content of carotene pigments was read at a wavelength of $448 \mu \mathrm{m}$. The values were expressed as $\mathrm{mg} \cdot \mathrm{g}^{-1}$ dry matter (DM).

\subsection{Statistical Analysis}

To calculate the means for Location I and for Location II, 12 and 16 experimental units were used, respectively. The mean values, standard deviation (SD) and coefficient of variation (CV) of the pigments content parameters were calculated. The coefficient of variation was assumed as the significance threshold when $15 \%$ was exceeded. Two-way analysis of variance (ANOVA) was carried out for each of the traits to assess the influence of the study location, the year and study location-year interaction on the content of plant pigments. The significance of differences between means was determined using the Tukey HSD test at the significance level of 0.05 and 0.01 . Next, correlations between the parameters and the content of minerals in the soil were calculated using Spearman's rank-order correlation. The Statistica v. 6.0 program (Statsoft, Poland) was used for the calculations.

\subsection{Weather Conditions}

There were differences in the weather conditions during the growing season in the years of the research (Table 1). The weather data came from the measurement station at the Experimental and Educational Facility Złotniki, Poznań University of Life Sciences, located near the villages of Bolechowo (in Location I) and Wojnówko (in Location II). The Selyaninov hydrothermal coefficient was used for a detailed assessment of rainfall and temperature in both growing seasons $[27,28]$. The following formula was used for calculations:

$$
\mathrm{k}=(p \cdot 10) / \Sigma \mathrm{t}
$$

where:

$p$ - the total monthly rainfall ( $\mathrm{mm}$ ),

$\Sigma \mathrm{t}$ - the monthly total of average daily air temperatures $>0{ }^{\circ} \mathrm{C}$. 
Table 1. Weather conditions during the vegetation period in the years 2007-2008.

\begin{tabular}{ccccccc}
\hline Month & Average Air Temperature $\left({ }^{\circ} \mathbf{C}\right)$ & \multicolumn{2}{c}{ Total Rainfall (mm) } & \multicolumn{2}{c}{ Selyaninov's Coeficient K } \\
\hline & $\mathbf{2 0 0 7}$ & $\mathbf{2 0 0 8}$ & $\mathbf{2 0 0 7}$ & $\mathbf{2 0 0 8}$ & $\mathbf{2 0 0 7}$ & $\mathbf{2 0 0 8}$ \\
\hline April & 12.7 & 10.0 & 7.4 & 77.5 & 0.19 & 2.58 \\
May & 16.8 & 16.2 & 73.1 & 9.5 & 1.40 & 0.19 \\
June & 20.6 & 20.6 & 44.3 & 8.4 & 0.72 & 0.14 \\
July & 19.9 & 22.2 & 72.2 & 46.6 & 1.17 & 0.68 \\
August & 20.6 & 19.7 & 65.7 & 88.6 & 1.03 & 1.45 \\
September & 14.6 & 14.4 & 32.6 & 16.8 & 0.74 & 0.39 \\
October & 9.0 & 9.9 & 20.3 & 9.4 & 0.73 & 0.31 \\
Mean/Sum & 16.3 & 16.1 & 315.6 & 256.8 & 0.85 & 0.82 \\
\hline
\end{tabular}

Value k—period: $\leq 0.40$ —extreme dry, 0.41-0.70—very dry, 0.71-1.00—dry, 1.01-1.30—quite dry, 1.31-1.60—optimum, 1.61-2.00-quite humid, 2.01-2.50—humid, 2.51-3.0—very humid, $>3.00$ —extremely humid.

There were similar average temperatures in the first and second year of the research $\left(16.3^{\circ} \mathrm{C}\right.$ and $16.1^{\circ} \mathrm{C}$ ). In 2007 there was good humidity, with short dry periods (April) during the growing season. 2008 was a less favourable year due to low rainfall in the key periods of initial plant development. In May the total rainfall was $9.5 \mathrm{~mm} \cdot \mathrm{m}^{2}$, in June $-8.4 \mathrm{~mm} \cdot \mathrm{m}^{2}$ and in July $-46.6 \mathrm{~mm} \cdot \mathrm{m}^{2}$. By comparison, in 2007 the rainfall in May was $73.1 \mathrm{~mm} \cdot \mathrm{m}^{2}$, in June $-44.3 \mathrm{~mm} \cdot \mathrm{m}^{2}$, and in July-72.2 $\mathrm{mm} \cdot \mathrm{m}^{2}$. It is noteworthy that between April and October 2008 the rainfall was $58.8 \mathrm{~mm} \cdot \mathrm{m}^{2}$ lower than in the previous year. If we assume the value of the hydrothermal coefficient $k$ as a determinant of rainfall and temperature, in 2008 May and June were extremely dry months, whereas July was very dry (Table 1).

\section{Results}

\subsection{Soil Conditions}

The soil conditions of the habitats during the two years of the research are shown in Tables 2 and 3.

Table 2. Characteristics of soil conditions of a forest habitat located in Location I (mg.100 $\mathrm{g}^{-1}$ soil).

\begin{tabular}{|c|c|c|c|c|c|}
\hline $\begin{array}{l}\text { Minerals and } \\
\text { Soil Reaction }\end{array}$ & Mean & Minimum & Maximum & Standard Deviation & Variation Coefficient (\%) \\
\hline \multicolumn{6}{|c|}{ Year $2007(n=3)$} \\
\hline $\mathrm{pH}$ & 3.56 & 3.32 & 3.76 & 0.22 & 6.2 \\
\hline $\mathrm{P}_{2} \mathrm{O}_{5}$ & 7.54 & 6.64 & 8.68 & 1.04 & 13.8 \\
\hline $\mathrm{K}_{2} \mathrm{O}$ & 6.09 & 5.18 & 6.78 & 0.82 & 13.4 \\
\hline $\mathrm{MgO}$ & 5.40 & 5.07 & 5.67 & 0.30 & 5.5 \\
\hline \multicolumn{6}{|c|}{ Year $2008(n=3)$} \\
\hline $\mathrm{pH}$ & 3.55 & 3.43 & 3.66 & 0.11 & 3.2 \\
\hline $\mathrm{P}_{2} \mathrm{O}_{5}$ & 6.79 & 6.42 & 7.12 & 0.35 & 5.1 \\
\hline $\mathrm{K}_{2} \mathrm{O}$ & 6.12 & 5.43 & 6.44 & 0.62 & 10.2 \\
\hline $\mathrm{MgO}$ & 5.34 & 5.13 & 5.57 & 0.22 & 4.1 \\
\hline \multicolumn{6}{|c|}{ Average over the years $(n=6)$} \\
\hline $\mathrm{pH}$ & 3.55 & 3.32 & 3.76 & 0.16 & 4.7 \\
\hline $\mathrm{P}_{2} \mathrm{O}_{5}$ & 7.16 & 6.42 & 8.68 & 0.69 & 9.5 \\
\hline $\mathrm{K}_{2} \mathrm{O}$ & 6.10 & 5.18 & 6.78 & 0.72 & 11.8 \\
\hline $\mathrm{MgO}$ & 5.37 & 5.07 & 5.67 & 0.26 & 4.8 \\
\hline
\end{tabular}


Table 3. Characteristics of soil conditions of a forest habitat located in Location II ( $\mathrm{mg} \cdot 100 \mathrm{~g}^{-1}$ soil).

\begin{tabular}{|c|c|c|c|c|c|}
\hline $\begin{array}{l}\text { Minerals and } \\
\text { Soil Reaction }\end{array}$ & Mean & Minimum & Maximum & Standard Deviation & Variation Coefficient (\%) \\
\hline \multicolumn{6}{|c|}{ Year $2007(n=3)$} \\
\hline $\mathrm{pH}$ & 3.37 & 3.18 & 3.62 & 0.22 & 6.7 \\
\hline $\mathrm{P}_{2} \mathrm{O}_{5}$ & 8.75 & 8.29 & 9.42 & 0.59 & 6.7 \\
\hline $\mathrm{K}_{2} \mathrm{O}$ & 6.89 & 6.32 & 7.46 & 0.57 & 8.2 \\
\hline $\mathrm{MgO}$ & 6.70 & 5.12 & 8.66 & 1.79 & 26.8 \\
\hline \multicolumn{6}{|c|}{ Year $2008(n=3)$} \\
\hline $\mathrm{pH}$ & 3.30 & 3.18 & 3.43 & 0.12 & 3.7 \\
\hline $\mathrm{P}_{2} \mathrm{O}_{5}$ & 8.03 & 7.42 & 8.66 & 0.57 & 7.1 \\
\hline $\mathrm{K}_{2} \mathrm{O}$ & 6.74 & 5.77 & 7.78 & 1.00 & 14.9 \\
\hline $\mathrm{MgO}$ & 6.28 & 5.57 & 6.88 & 0.66 & 10.5 \\
\hline \multicolumn{6}{|c|}{ Average over the years $(n=6)$} \\
\hline $\mathrm{pH}$ & 3.33 & 3.18 & 3.62 & 0.17 & 5.2 \\
\hline $\mathrm{P}_{2} \mathrm{O}_{5}$ & 8.39 & 7.42 & 9.42 & 0.58 & 6.9 \\
\hline $\mathrm{K}_{2} \mathrm{O}$ & 6.81 & 5.77 & 7.78 & 0.78 & 11.5 \\
\hline $\mathrm{MgO}$ & 6.49 & 5.12 & 8.66 & 1.22 & 18.6 \\
\hline
\end{tabular}

During the two years of the research, the average content of soil minerals at the forest sites in Location I was: $7.16 \mathrm{mg} \mathrm{P}_{2} \mathrm{O}_{5}, 6.10 \mathrm{mg} \mathrm{K} \mathrm{O}_{2}$, and $5.37 \mathrm{mg} \mathrm{MgO}$ per $100 \mathrm{~g}$ of soil with $\mathrm{pH}=3.5$. The soil in the Melica nutans habitat in Location II was slightly more abundant in nutrients, i.e., $8.39 \mathrm{mg} \mathrm{P}_{2} \mathrm{O}_{5}$, $6.81 \mathrm{mg} \mathrm{K}_{2} \mathrm{O}$, and $6.49 \mathrm{mg} \mathrm{MgO}$ per $100 \mathrm{~g}$ of soil with $\mathrm{pH}=3.33$.

\subsection{Content of Chlorophyll Pigments}

The analyses revealed that both the forest habitats and individual plants within the same habitat differed significantly in the content of chlorophyll pigments.

The average content of chlorophyll $a$ in Melica nutans plants at the forest sites in Location I was $6.67 \pm 0.99 \mathrm{mg} \cdot \mathrm{g}^{-1} \mathrm{DM}$. with fluctuations from 5.09 to $8.77 \mathrm{mg} \cdot \mathrm{g}^{-1} \mathrm{DM}$. The difference between the extreme values of the content of this dye was $3.68 \mathrm{mg} \cdot \mathrm{g}^{-1} \mathrm{DM}$. (72.3\%). The average content of chlorophyll $b$ in the same plants was $2.44 \pm 0.39 \mathrm{mg} \cdot \mathrm{g}^{-1} \mathrm{DM}$. and ranged from 1.79 to $3.63 \mathrm{mg} \cdot \mathrm{g}^{-1} \mathrm{DM}$. The average chlorophyll $a: b$ ratio was 2.7. The content of chlorophyll $(a+b)$ in individual plants was diversified and ranged from 6.92 to $11.69 \mathrm{mg} \cdot \mathrm{g}^{-1} \mathrm{DM}$. The average content was $9.11 \pm 1.28 \mathrm{mg} \cdot \mathrm{g}^{-1}$ $\mathrm{DM}$. The difference between the extreme values of the content of these pigments was $4.77 \mathrm{mg} \cdot \mathrm{g}^{-1} \mathrm{DM}$ $(68.9 \%)$. The coefficient of variation for the content of chlorophyll $(a+b)$ was $14.16 \%$ and it was not significant (Table 4).

Table 4. Characteristics of the variability of chlorophyll and carotene pigments content in Melica nutans leaf blades from two forest stands (mg.g $\left.{ }^{-1} \mathrm{DM}\right)$.

\begin{tabular}{|c|c|c|c|c|c|}
\hline Plant Pigments & Mean & Minimum & Maximum & Standard Deviation & Variation Coefficient (\%) \\
\hline \multicolumn{6}{|c|}{ Location I $(n=12)$} \\
\hline Chlorophyll $a$ & 6.67 & 5.09 & 8.77 & 0.99 & 14.87 \\
\hline Chlorophyll $b$ & 2.44 & 1.79 & 3.63 & 0.39 & 16.36 \\
\hline Chlorophyll $(a+b)$ & 9.11 & 6.92 & 11.69 & 1.28 & 14.16 \\
\hline$\beta$-carotene & 0.61 & 0.42 & 0.92 & 0.11 & 17.32 \\
\hline Carotene sum & 1.60 & 1.21 & 1.94 & 0.21 & 13.10 \\
\hline \multicolumn{6}{|c|}{ Location II $(n=16)$} \\
\hline Chlorophyll $a$ & 7.76 & 6.04 & 9.29 & 0.96 & 12.39 \\
\hline Chlorophyll $b$ & 2.36 & 1.61 & 2.96 & 0.26 & 11.57 \\
\hline Chlorophyll $(a+b)$ & 10.13 & 7.65 & 12.14 & 1.18 & 11.73 \\
\hline$\beta$-carotene & 0.62 & 0.46 & 0.83 & 0.07 & 11.35 \\
\hline Carotene sum & 1.40 & 0.93 & 1.79 & 0.19 & 14.06 \\
\hline
\end{tabular}


The mountain melick plants from Location II had a higher content of chlorophyll $a$, i.e., $7.76 \mathrm{mg} \cdot \mathrm{g}^{-1}$ $\mathrm{DM}$, with fluctuations from 6.04 to $9.29 \mathrm{mg} \cdot \mathrm{g}^{-1} \mathrm{DM}$. The difference between the extreme values of this parameter was $3.25 \mathrm{mg} \cdot \mathrm{g}^{-1} \mathrm{DM}$. The coefficient of variation for this trait was lower than that of the plants growing in Location I and amounted to $12.39 \%$, with the standard deviation of $0.96 \mathrm{mg} \cdot \mathrm{g}^{-1}$ DM. The content of chlorophyll $b$ in the Melica nutans plants from the forest habitat in Location I was $0.08 \mathrm{mg} \cdot \mathrm{g}^{-1} \mathrm{DM}(3.4 \%)$ higher than in Location II, but the difference was not statistically significant (Table 5). The chlorophyll $a: b$ ratio was also higher, i.e., 3.2. The average content of chlorophyll $(a+b)$ in the plants from this habitat was $10.13 \pm 1.18 \mathrm{mg} \cdot \mathrm{g}^{-1} \mathrm{DM}$, with fluctuations from 7.65 to $12.14 \mathrm{mg} \cdot \mathrm{g}^{-1}$ DM. The difference between the extreme levels of chlorophyll $(a+b)$ was $4.49 \mathrm{mg}^{-1} \mathrm{~g}^{-1} \mathrm{DM}$. (58.7\%). The coefficient of variation amounted to $11.73 \%$ and it was not significant (Table 4 ).

Table 5. Results of two-way ANOVA between stands location and year of study on chlorophyll and carotene pigments content in Melica nutans leaf blades (mg.g $\left.{ }^{-1} \mathrm{DM}\right)$.

\begin{tabular}{cccccccc}
\hline Plant Pigments & \multicolumn{2}{c}{ Forest Habitat } & \multicolumn{2}{c}{ Year of Study } & \multicolumn{3}{c}{ Significance } \\
\hline & Location I & Location II & Year 1 & Year 2 & Location & Year & Interaction \\
\hline Chlorophyll $a$ & 6.67 & 7.77 & 7.64 & 6.95 & $* *$ & $*$ & $*$ \\
Chlorophyll $b$ & 2.44 & 2.37 & 2.66 & 2.14 & $\mathrm{~ns}$ & $* *$ & $* *$ \\
Chlorophyll $(a+b)$ & 9.12 & 10.14 & 10.30 & 9.09 & $* *$ & $* *$ & $*$ \\
ß-carotene & 0.61 & 0.62 & 0.66 & 0.58 & $\mathrm{~ns}$ & $* *$ & $*$ \\
Total carotenoids & 1.60 & 1.41 & 1.53 & 1.46 & $* *$ & $\mathrm{~ns}$ & $*$ \\
\hline
\end{tabular}

The comparison of the content of chlorophyll pigments in the plants from both forest habitats, showed that the Melica nutans plants growing in Location II had a significantly higher content of chlorophyll $a$ and chlorophyll $(a+b)$ than the plants in Location I (Table 5). The difference in the content of chlorophyll $a$ between the habitats was $1.09 \mathrm{mg} \cdot \mathrm{g}^{-1} \mathrm{DM}$. (16.3\%). The content of chlorophyll $(a+b)$ in the leaves of the Melica nutans plants growing in Location II was $1.02 \mathrm{mg} \cdot \mathrm{g}^{-1} \mathrm{DM}$. (11.2\%) higher than in the plants from Location I.

The year of the research was also the factor that significantly differentiated the content of the pigments under analysis. The average content of all chlorophyll pigments in Melica nutans plants in the first year of the research was significantly higher than in the second year, regardless of the plants' habitat (Table 5).

The analysis also revealed the interaction of both factors, i.e., the habitat and the research year. The comparison of the content of chlorophyll pigments in the plants collected from the sites in Location I showed that in the first year of the study it was higher than in the second year (Figures 1-3). The differences between the years were: $0.84 \mathrm{mg} \cdot \mathrm{g}^{-1} \mathrm{DM} .(13 \%)$ for chlorophyll $a, 0.59 \mathrm{mg} \cdot \mathrm{g}^{-1} \mathrm{DM}$. (27\%) for chlorophyll $b$, and $1.43 \mathrm{mg} \cdot \mathrm{g}^{-1} \mathrm{DM}$. (17\%) for chlorophyll $(a+b)$.

There was a similar dependence observed in the plants from Location II, but the differences were slightly smaller (Figures 1-3). The content of chlorophyll pigments in these plants in the first year of the study was higher than in the second year. The differences were: $0.59 \mathrm{mg} \cdot \mathrm{g}^{-1} \mathrm{DM}$. (almost $8 \%$ ) for chlorophyll $a, 0.45 \mathrm{mg} \cdot \mathrm{g}^{-1} \mathrm{DM}$. (21\%) for chlorophyll $b$, and $1.05 \mathrm{mg} \cdot \mathrm{g}^{-1} \mathrm{DM}$ (almost $11 \%$ ) for chlorophyll $(a+b)$. 


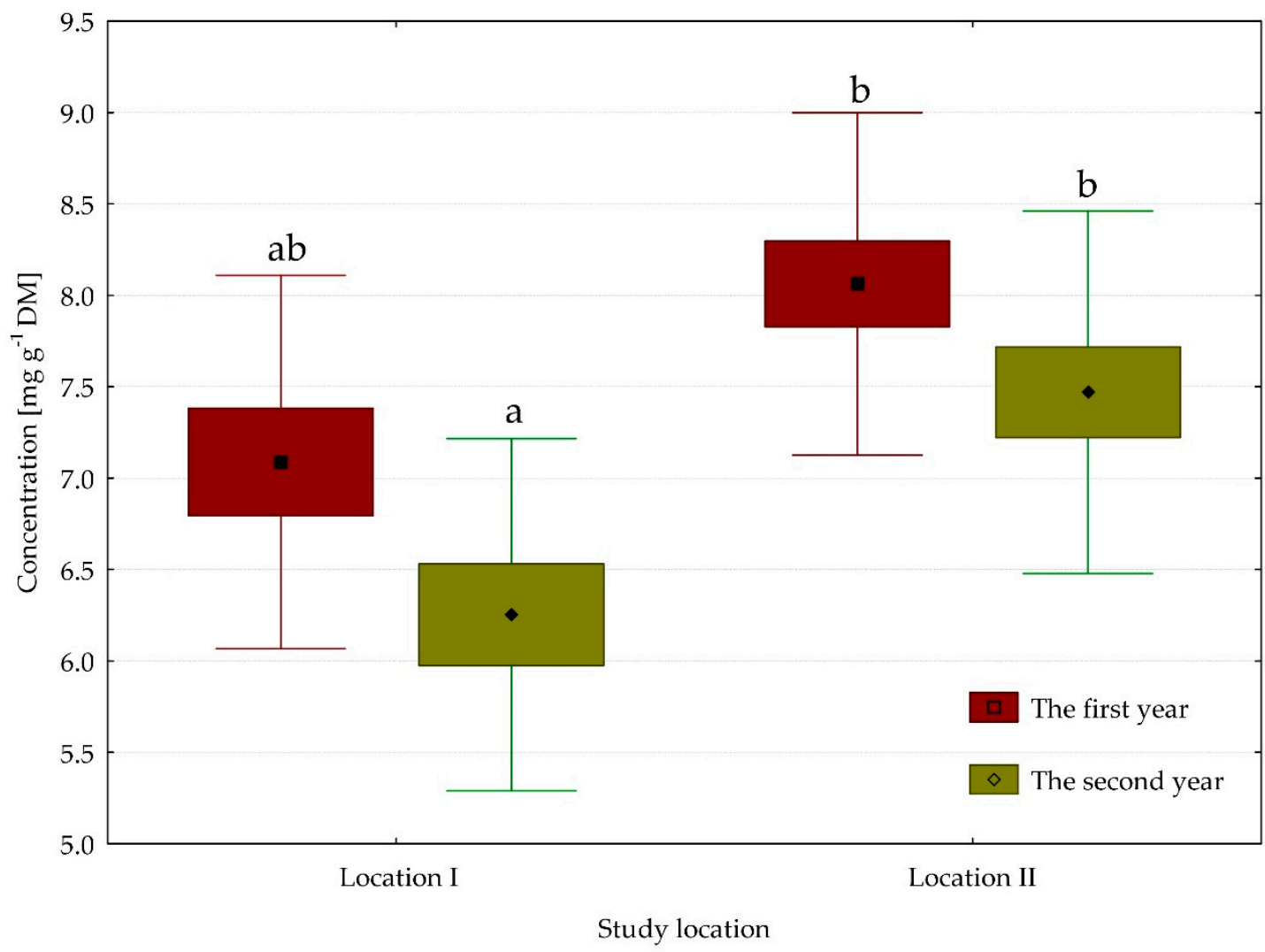

Figure 1. Chlorophyll a content in Melica nutans leaf blades from two natural forest stands.

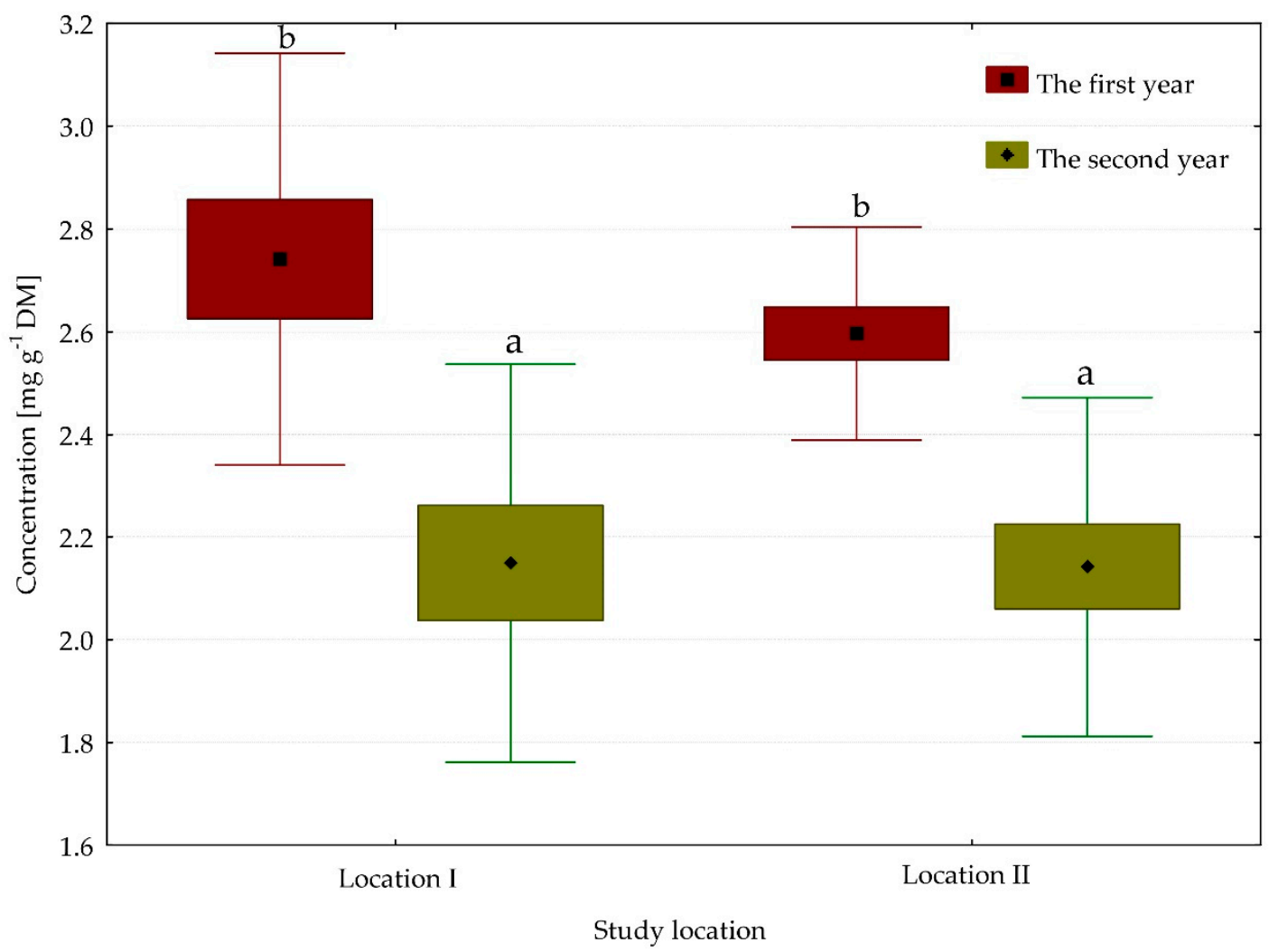

Figure 2. Chlorophyll $b$ content in Melica nutans leaf blades from two natural forest stands. 


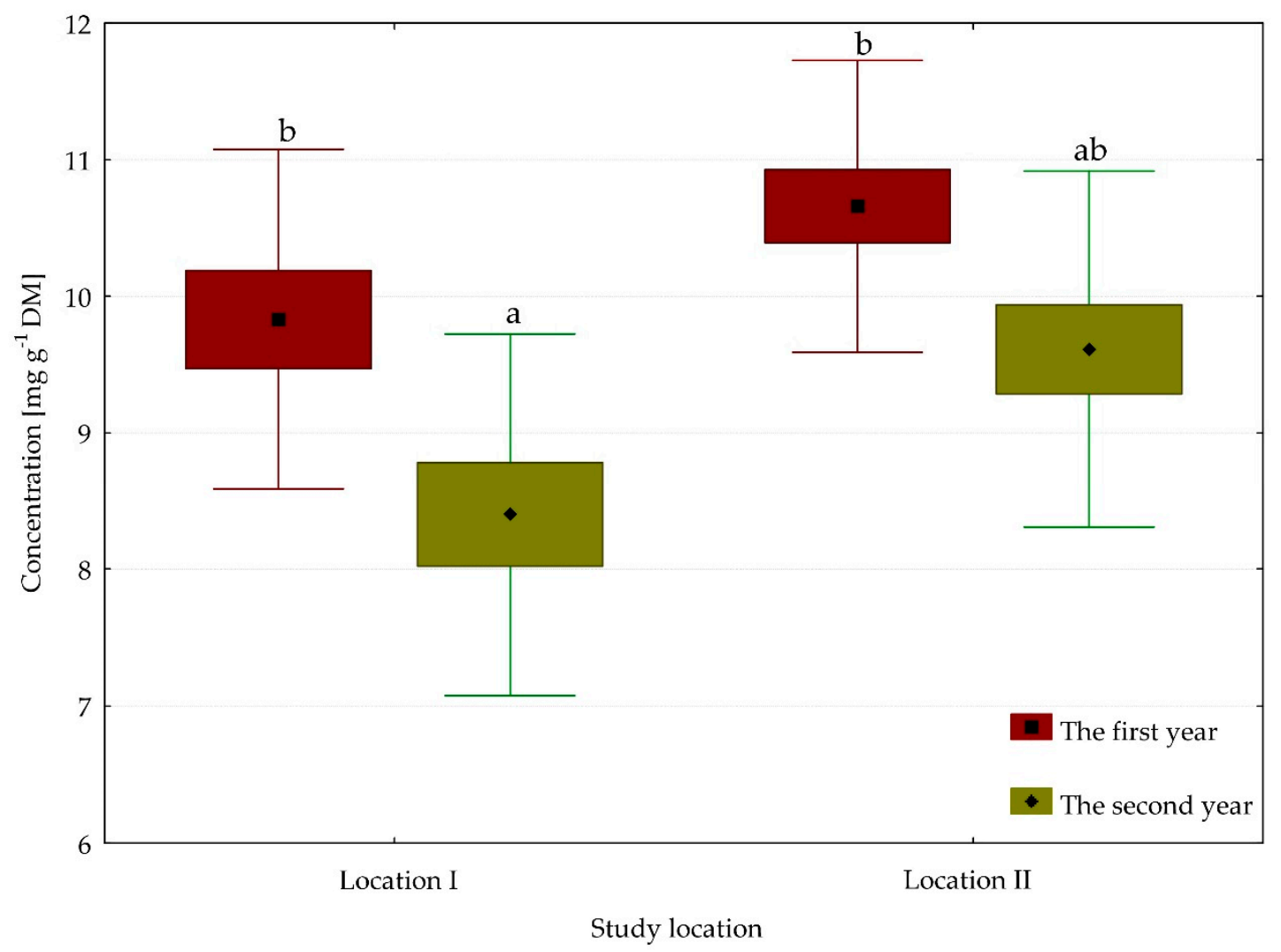

Figure 3. Chlorophyll $(a+b)$ content in Melica nutans leaf blades from two natural forest stands.

\subsection{Content of Carotene Pigments}

The comparison of the mean content of carotene pigments in the leaf blades of Melica nutans plants collected from both habitats did not reveal significant differences in the $\beta$-carotene content. It amounted to $0.61 \pm 0.11 \mathrm{mg} \cdot \mathrm{g}^{-1} \mathrm{DM}$. in the plants from the sites in Location I, whereas the $\beta$-carotene content in the plants collected from the other habitat was $0.62 \pm 0.07 \mathrm{mg} \cdot \mathrm{g}^{-1} \mathrm{DM}$. Although the mean values were similar, the content of $\beta$-carotene in the plants from Location I was highly diversified, because the coefficient of variation was significant and amounted to $17.32 \%$. The content of this dye in the leaves of the plants collected from the sites in Location II was less diversified-the coefficient of variation was $11.35 \%$ (Table 4 ).

Although the content of $\beta$-carotene was similar, there were significant differences in the total carotene content and the ratio of carotenes to chlorophyll pigments. The total carotene content in the leaves of the Melica nutans plants collected from Location I was $1.1 \pm 0.21 \mathrm{mg} \cdot \mathrm{g}^{-1} \mathrm{DM}$. and it was significantly higher than in the leaves of the plants from Location II, where it exceeded $1.4 \pm 0.19 \mathrm{mg} \cdot \mathrm{g}^{-1}$ $\mathrm{DM}$. The ratio of carotenes to chlorophyll pigments in the leaves of the mountain melick plants from Location I was higher and amounted to 0.17 , whereas in the plants from Location II it was only 0.14 .

The year of the research also significantly differentiated the content of $\beta$-carotene, which was in the first year significantly higher than in the second year (Table 5). The total carotene content in 2007 was also higher than in 2008 , although this difference was not statistically significant (Table 5). The ratio of total carotenes to chlorophyll pigments in the first year was 0.15 , whereas in the second year it was slightly higher, i.e., 0.16 (Figure 4).

The analysis of the content of carotene pigments in the mountain melick plants collected from the sites in Location I revealed that, similarly to chlorophyll pigments, in the first year of the study, the concentration of $\beta$-carotene in the plants was $0.14 \mathrm{mg} \cdot \mathrm{g}^{-1} \mathrm{DM}$. (almost $25 \%$ ) higher than in the second year (Figure 5). The coefficient of variation was high and significant, i.e., 23\%. However, 
the total carotene content was $0.07 \mathrm{mg} \cdot \mathrm{g}^{-1} \mathrm{DM}$ lower $(4.5 \%)$ than in the second year of the study (Figure 6).

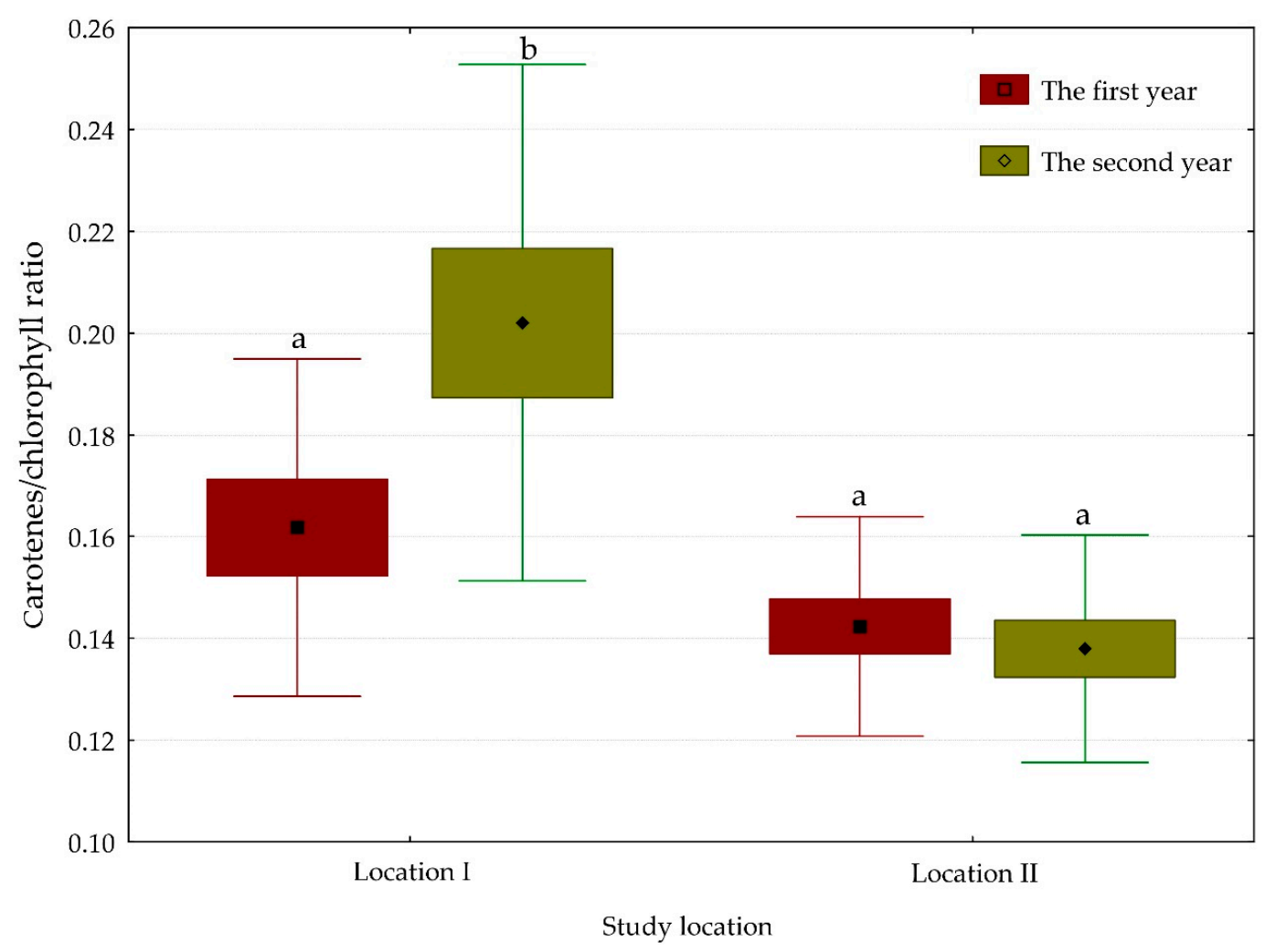

Figure 4. The ratio of carotenes to chlorophyll pigments in Melica nutans leaf blades from two natural forest stands.

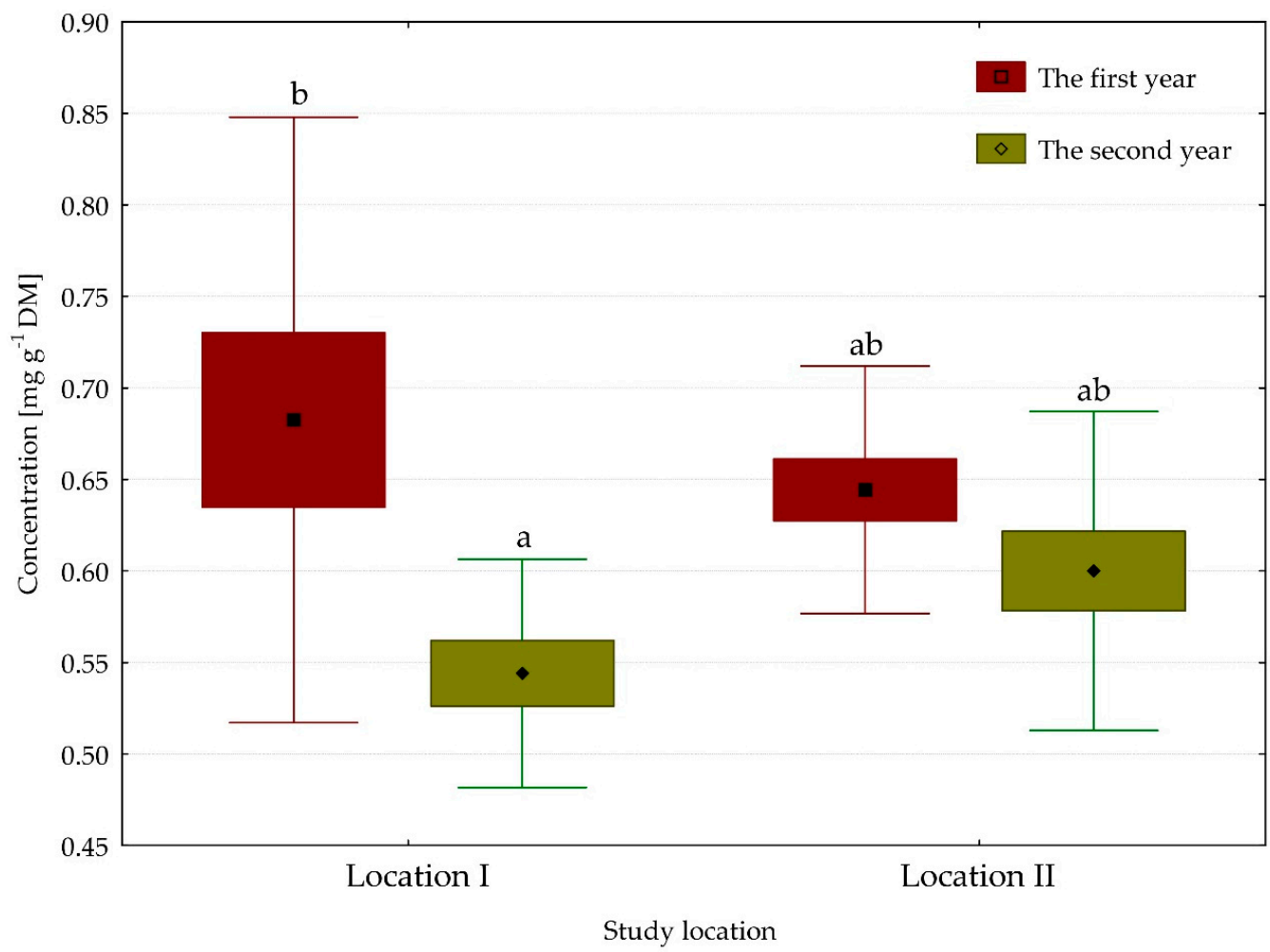

Figure 5. $\beta$-carotene content in Melica nutans leaf blades from two natural forest stands. 


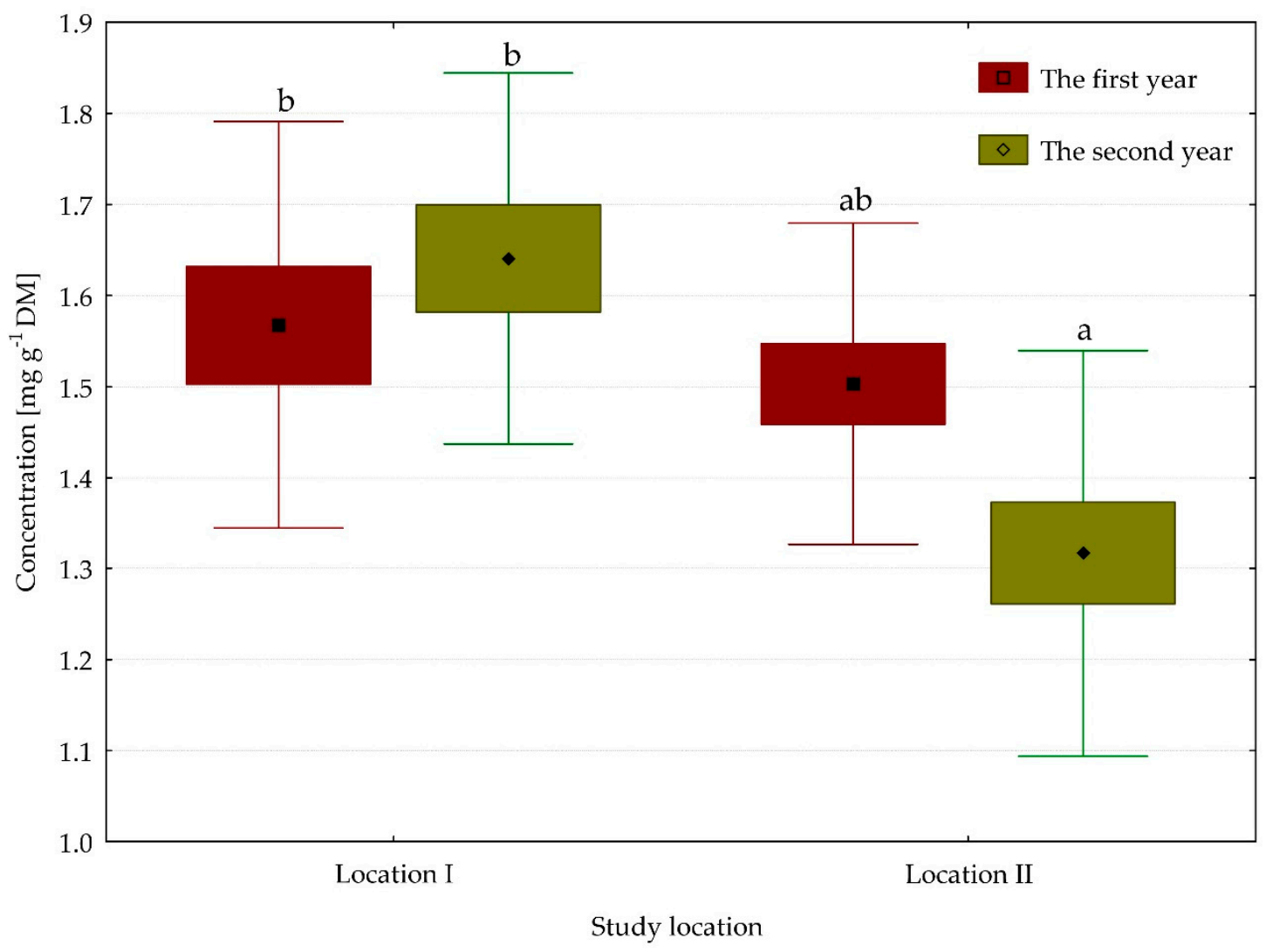

Figure 6. Carotene sum content in Melica nutans leaf blades from two natural forest stands.

Both the $\beta$-carotene and total carotene content in the plants collected from the sites in Location II was higher in the first year of the study (Figures 5 and 6). The difference in the $\beta$-carotene content between the years was $0.04 \mathrm{mg} \cdot \mathrm{g}^{-1} \mathrm{DM} .(6.6 \%)$, whereas the difference in the total carotene content amounted to $0.19 \mathrm{mg} \cdot \mathrm{g}^{-1} \mathrm{DM}(14.5 \%)$.

\section{Discussion}

There are few publications on the content of assimilation pigments in the leaves of forest grasses growing in Poland $[15,29]$. So far there have mainly been publications concerning research on species of cultivated grasses $[12,30]$.

According to Kozłowski et al. [15], the content of chlorophyll $(a+b)$ in the leaf blades of grasses may vary considerably and range from 5.50 to as much as $20.38 \mathrm{mg} \cdot \mathrm{g}^{-1} \mathrm{DM}$. The authors observed the highest content of chlorophyll $(a+b)$ in sciophilous species growing on fertile soils in deciduous forests and parks, in places with different degrees of shade. These were forest grass species such as:

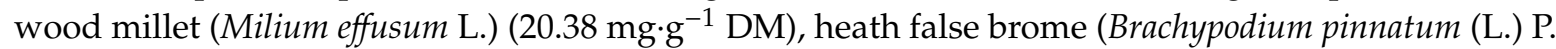
Beauv.) (18.84 $\left.\mathrm{mg} \cdot \mathrm{g}^{-1} \mathrm{DM}\right)$ and wood bluegrass (Poa nemoralis L.) $\left(9.5 \mathrm{mg} \cdot \mathrm{g}^{-1} \mathrm{DM}\right)$. Kozłowski and Zielewicz [29] found also a high content of chlorophyll $(a+b)$ in forest grass species The content of these pigments was over $10.0 \mathrm{mg} \cdot \mathrm{g}^{-1} \mathrm{DM}$ of leaf blades. The coefficient of variation ranged from $4 \%$ to $25 \%$, which indicated high diversity. The content of chlorophyll $(a+b)$ in mountain melick plants (Melica nutans) was slightly lower, i.e., $9.9 \mathrm{mg} \cdot \mathrm{g}^{-1} \mathrm{DM}$., and fluctuated from 6.24 to $14.18 \mathrm{mg} \cdot \mathrm{g}^{-1} \mathrm{DM}$. The coefficient of variation was high, i.e., $21 \%$ [29].

In our study, the average content of chlorophyll $(a+b)$ in the leaf blades of the Melica nutans plants from both habitats was $9.62 \mathrm{mg} \cdot \mathrm{g}^{-1} \mathrm{DM}(\mathrm{CV}=13.7 \%)$. This was similar to the value observed in this species by Zielewicz and Kozłowski [29]. It is noteworthy that like in our study, the material used by these authors came from plants collected in summer, which grew in habitats with similar soil and light conditions. 
The comparison of the range of chlorophyll content in forest grasses noted in our study and other authors' research revealed considerable similarity to the content of these pigments in cultivated nitrophilous grass species. For example, according to Zielewicz and Kozłowski [12], the content of these pigments in sorghum plants was $8.24 \mathrm{mg} \cdot \mathrm{g}^{-1} \mathrm{DM}$, whereas in the leaf blades of perennial ryegrass (Lolium perenne L.) it was $8.50 \mathrm{mg} \cdot \mathrm{g}^{-1} \mathrm{DM}$ in diploid cultivars and $9.31 \mathrm{mg} \cdot \mathrm{g}^{-1} \mathrm{DM}$ in tetraploid cultivars [30].

Some species of forest grasses have not only high content of chlorophyll pigments but also their content of chlorophyll $a$ is almost three times greater than the content of chlorophyll $b$ [29]. The chlorophyll $a: b$ ratio in the Melica nutans plants growing in the less fertile forest habitat (Location I) was not high and amounted to 2.7. The chlorophyll $a: b$ ratio in the mountain melick plants growing in the forest habitat in a more fertile site (Location II) was much higher, i.e., 3.2. The result of our study is consistent with the findings of the research by Zielewicz and Kozłowski [29], who noted that the content of chlorophyll $a$ in all forest grasses analysed in their study was at least two times greater than the content of chlorophyll $b$. Sometimes it was even three times greater. The chlorophyll $a: b$ ratio in the mountain melick plants analysed by Zielewicz and Kozłowski [29] was 2.86.

Antioxidants contained in the fat of roughage, provided to animals in the form of green forage, deserve special attention in their nutrition. These are mainly carotenoids and tocopherols, which are also provitamins of vitamins $A$ and $E$ and $\beta$-carotene. There are about 600 types of carotenoids, but only some of them act on animal and human bodies [31]. $\beta$-carotene converts into vitamin A (retinol and retinal) the most effectively. There is a close relationship between the amount of $\beta$-carotene taken from the feed and the number of its reserves in animal bodies and its concentration in milk [32]. The content of $\beta$-carotene is influenced by various factors, such as: the plant species, phase of development and agrotechnical treatments. The content of $\beta$-carotene in the feed given to animals depends on its concentration in plants and the coefficient of degradation during harvesting and conservation [33]. The greatest amount of $\beta$-carotene is accumulated in the plastids in leaves, where the content of carotenoids is $5-10$ times greater than in the stems. The average content of lutein, zeaxanthin, epilutein and $\beta$-carotene in the grasses that are most often used as feed, e.g., cocksfoot (Dactylis glomerata $\mathrm{L}$.) and perennial ryegrass (Lolium perenne L.), is 630, 120, 80 and $170 \mathrm{~g} \cdot \mathrm{kg}^{-1} \mathrm{DM}$, respectively. According to Chauveau-Duriot et al. [34], brome Bromus inermis Leyss., reed canary grass (Phalaris arundinacea L.) and red clover (Trifolium pratense L.) contain $25 \%-50 \%$ more carotenoids than perennial ryegrass. As vegetation progresses, the content of carotenoids in plants decreases. The study by Prache et al. [35] showed that there were relatively small changes in the concentration of carotenoids in the grass sward of a pasture between May and June $\left(0.62-0.70 \mathrm{mg} \cdot \mathrm{g}^{-1} \mathrm{DM}\right)$. In late summer, at the beginning of August, the concentration of carotenoids decreased to $0.43 \mathrm{mg} \cdot \mathrm{g}^{-1} \mathrm{DM}$. The content of carotene pigments in plants depends to a large extent on the ratio of the weight of leaves to the weight of stems. The study by Reynoso et al. [36] showed that the content of lutein and $\beta$-carotene in green plants of the same species cultivated in a humid climate was 2-3 times higher than in the plants grown in a dry climate. Noziere et al. [33] observed that the total content of carotenoids in maize was $0.70-0.80 \mathrm{mg} \cdot \mathrm{g}^{-1}$ DM, i.e., 5-10 times lower than in other grasses used as fodder. Changes in the $\beta$-carotene content within one plant mostly depend on the stage of vegetation, weather conditions and the method of conservation. If the weather conditions are favourable during the growing season, an increase in the yield of green mass causes an increase in the content of carotenoids [36]. Williams et al. [37] observed that the average content of $\beta$-carotene in green fodder, dried grass, silage and hay amounted to 196, 159,81 and $36 \mathrm{mg} \cdot \mathrm{kg}^{-1} \mathrm{DM}$, respectively. According to Kalač [38], haylage from meadow grasses, legume plants or legume-grass mixtures could be a valuable source of both vitamin $E$ and $\beta$-carotene for animals. If cows are fed silage made from very high-quality plant components, large amounts of milk with the desired content of functional ingredients can be produced, which will positively affect consumers' health [39]. The same rule applies to herbivorous wild animals inhabiting forests. Grasses growing in these areas are a valuable source of carotene for these animals. 
In our study, the total carotene content in the mountain melick plants growing in the less fertile site (Location I) was $1.1 \mathrm{mg} \cdot \mathrm{g}^{-1} \mathrm{DM}$, whereas and in the more fertile site (Location II) it exceeded $1.4 \mathrm{mg} \cdot \mathrm{g}^{-1} \mathrm{DM}$. Similarly to the findings of our research, Zielewicz and Kozłowski [29] found a very high content of carotene pigments, i.e., up to about $1.0 \mathrm{mg} \cdot \mathrm{g}^{-1} \mathrm{DM}$. in such forest species as: heath false brome (Brachypodium pinnatum), mountain melick (Melica nutans), and wood melick (Melica uniflora). The authors found a slightly lower content of carotene pigments in wood small-reed (Calamagrostis epigejos (L.) Roth) $-0.83 \mathrm{mg} \cdot \mathrm{g}^{-1} \mathrm{DM}$, false brome (Brachypodium sylvaticum) $-0.74 \mathrm{mg} \cdot \mathrm{g}^{-1} \mathrm{DM}$, and wood millet (Milium effusum L.) - $0.73 \mathrm{mg} \cdot \mathrm{g}^{-1} \mathrm{DM}$. There was a very low level of total carotenes in the leaf blades of such forest grasses as: Benekena bromus (Bromus benekenii (Lange) Trimen-0.53 $\mathrm{mg} \cdot \mathrm{g}^{-1} \mathrm{DM}$ ) and purple moor grass (Molinia caerulea (L.) Moench) $-0.54 \mathrm{mg} \cdot \mathrm{g}^{-1} \mathrm{DM}$. If the quantity of carotene pigments in forest grasses is viewed through the prism of their presence in nitrophilous species of cultivated grasses, we can say that mountain melick (Melica nutans) could be a valuable source of vitamin A for forest animals due to the high content of these pigments in this plant [22].

The research on the content of photosynthetic pigments in Melica nutans plants was conducted to compare plants of this species growing in two different forest habitats, where the soil and moisture conditions were slightly different. There was significantly higher content of chlorophyll $a$ in Melica nutans plants growing at the forest sites in more fertile forest habitat (Location II). This effect may have been caused by slightly higher abundance of soil minerals in this habitat, especially higher content of magnesium (Table 3). This may have favoured higher uptake of this nutrient by plants and its incorporation into chlorophyll rings. Our observations were similar to the findings of the study by Grzebisz et al. [40]. Appropriate mineral fertilisation with both macro- and microelements provides adequate conditions for the synthesis of chlorophyll and increases plant productivity [41]. This fact was confirmed by the positive correlation between the content of $\mathrm{MgO}, \mathrm{K}_{2} \mathrm{O}$ and $\mathrm{P}_{2} \mathrm{O}_{5}$ in the soil and the content of chlorophyll $a$ and the sum of chlorophyll $(a+b)$ (Table 6). Magnesium is believed to be particularly important, because it is the central atom in the chlorophyll molecule and it participates in various physiological processes. Its deficiency causes a decrease in the content of green pigments, especially in older leaves. Tomaszewski et al. [42] found that magnesium fertilisation had a positive effect on the content of chlorophyll, especially at the phase of the most intensive plant growth, i.e., during the heading and flowering phases. $\mathrm{Mg}$ nutritional status in plants significantly affects the efficiency of photosynthesis, chlorophyll content, $\mathrm{CO}_{2}$ fixation by plants, transport of assimilates and is an important yield-forming factor $[43,44]$.

Table 6. Spearman's rank-order correlation coefficients between the content of chlorophyll pigments in the leaves and the mineral content of the soil.

\begin{tabular}{ccccc}
\hline Plant Pigments & \multicolumn{4}{c}{ Soil Parameters } \\
\hline & $\mathbf{p H}$ & $\mathbf{P}_{\mathbf{2}} \mathbf{O}_{5}$ & $\mathbf{K}_{\mathbf{2}} \mathbf{O}$ & $\mathbf{M g O}$ \\
\hline Chlorophyll $a$ & -0.25 & $0.55^{* *}$ & $0.44^{* *}$ & $0.55^{* *}$ \\
Chlorophyll $b$ & $0.38^{* *}$ & 0.22 & -0.01 & 0.22 \\
Chlorophyll $(a+b)$ & -0.08 & $0.48^{* *}$ & $0.32 *$ & $0.48^{* *}$ \\
$\beta$-carotene & 0.08 & $0.29^{*}$ & 0.11 & $0.29^{*}$ \\
Carotene sum & $0.41^{* *}$ & $-0.28^{*}$ & -0.23 & $-0.28^{*}$ \\
\hline & $*<0.05 ; * * 0.01$. \\
\end{tabular}

The soil abundance of potassium in both forest habitats was at a similar level (Location I-6.10 mg $\mathrm{K}_{2} \mathrm{O} \cdot 100 \mathrm{~g}^{-1}$ soil and Location II-6.81 $\mathrm{mg} \mathrm{K}_{2} \mathrm{O} \cdot 100 \mathrm{~g}^{-1}$ soil). Therefore, no significant effect of this macroelement on the content of chlorophyll and carotene pigments in mountain melick plants was observed.

Higher phosphorus content in the soil in Location II had also a significant effect on the content of chlorophyll pigments and the intensity of physiological processes in mountain melick plants. According to Kavanová [45] phosphorus deficiency in the soil causes a decrease in speed of cell division in leaf 
bud and a decrease in their elongation. Too low a phosphorus content in the soil causes a decrease in the efficiency of nitrogen uptake by plants, which is also manifested by a lower content of chlorophyll pigments in plants. Some fodder grass species such as Lolium perenne L., Lolium multiflorum Lam. and Poa pratensis L. show a strong positive reaction to the higher phosphorus content in the soil [46].

Forest grasses grow in difficult habitats and have various functions, the most important of which is the turf-forming function. Many researchers emphasise the role of light as a factor affecting both the morphological and biological properties of plants, including the content of chlorophyll pigments [17].

Species growing under low light conditions usually try to optimise the capturing and use of light by increasing the leaf area, reducing the chlorophyll $a: b$ ratio, and increasing the photosystem II:I ratio $[47,48]$. It is noteworthy that the Melica nutans plants analysed in this study grew in the specific conditions of forest habitats. Grasses growing in such locations usually have a much higher content of chlorophyll $(a+b)$ than grasses growing in fields or meadows, where there is good access to light. Kozłowski et al. [15] observed that under such conditions the content of chlorophyll $(a+b)$ in nitrophilous grasses, e.g., perennial ryegrass (Lolium perenne L.), was $7.79 \mathrm{mg} \cdot \mathrm{g}^{-1} \mathrm{DM}$. , in meadow fescue (Festuca pratensis Huds.) - only $6.55 \mathrm{mg} \cdot \mathrm{g}^{-1} \mathrm{DM}$, whereas in mountain melick it sometimes even exceeded $12 \mathrm{mg} \cdot \mathrm{g}^{-1} \mathrm{DM}$. Our results were also similar to the results of studies on several dicotyledons [49] and monocotyledons [50]. The research showed that the chlorophyll content in plants may decrease along with lower intensity of solar radiation.

The analysis of the influence of the weather conditions on the content of chlorophyll pigments showed that in both years of the research during the growing season the average temperatures were similar. In the first year, the average temperature was $14.6^{\circ} \mathrm{C}$, whereas in the second year it was $14.8^{\circ} \mathrm{C}$. Both years differed in humidity during the growing season. In the first year, the total rainfall between May and July was $189 \mathrm{~mm} \cdot \mathrm{m}^{2}$. The total rainfall in this period in the second year of the research was much lower, i.e., $64.5 \mathrm{~mm} \cdot \mathrm{m}^{2}$ - it was $125.1 \mathrm{~mm} \cdot \mathrm{m}^{2}$ lower than in the first year. The distribution of rainfall in the second year was very unfavourable for plants-only $9.5 \mathrm{~mm} \cdot \mathrm{m}^{2}$ in May and $8.4 \mathrm{~mm} \cdot \mathrm{m}^{2}$ in June. The rainfall in July did not improve the situation-it was slightly over $46 \mathrm{~mm} \cdot \mathrm{m}^{2}($ Table 1$)$. The samples of plants were collected for analyses during this period. The lower rainfall and its unfavourable distribution, regardless of the site from which the plants were collected, may have significantly contributed to the occurrence of moisture stress, which resulted in lower content of chlorophyll pigments in the leaf blades.

Drought stress reduces the content of chlorophyll pigments and carotenes and changes the ratio of chlorophyll $b$ to chlorophyll $a$ [51-53]. It also significantly reduces the intensity of photosynthesis [54]. Olszewska [24] observed that the concentration of chlorophyll in forage grasses grown in the field during water stress was significantly higher than in grasses grown at optimal soil moisture. In another study, Olszewska et al. [55] found that the content of chlorophyll in the leaf blades was also mainly influenced by soil moisture. There was a higher concentration of chlorophyll in the leaves of plants grown under stress conditions. According to Olszewska [24], water deficit causes leaf cells to shrink and tissues to thicken. As a consequence, there is a higher concentration of low- and high-molecular compounds, including chlorophyll. In our study, the reaction of mountain melick plants was different from the observations made by Olszewska [24,55]. In the second year of the study, the drought stress in the forest significantly reduced the concentration of chlorophyll pigments and $\beta$-carotene in the leaves of the mountain melick plants. The different reaction of Melica nutans plants could be explained by the specific conditions of the forest habitat in which forest species are not subjected to high temperatures and intensive sunlight like other grasses growing in the field conditions.

The results of our research on the biological properties of Melica nutans broaden the knowledge about this group of forest grasses and supplement the data presented in reference publications and collected by Falkowski [56] as well as the information contained in the monograph by Falkowski et al. [57]. 


\section{Conclusions}

The unfavourable precipitation distribution during the growing season, and in particular, the stressful drought conditions, as it was observed from May to July in the second year of the study, caused a decrease in the concentration of chlorophyll and carotene pigments in the mountain melick plants.

Based on the obtained results, it can be concluded that the higher abundance of the macroelements such as Mg and P in soil in Location II resulted in a higher content of chlorophyll pigments and a lower content of carotene pigments in the mountain melick plants.

Soil abundance of $\mathrm{K}$ in both forest habitats was at a similar level and therefore no significant effect of this macroelement on the content of chlorophyll and carotene pigments in plants was obtained.

The mountain melick is still a little known grass species growing in the natural forest habitats. Based on the obtained results concerning the content of plant pigments such as chlorophyll and carotene, it can be concluded that mountain melic plants can be a valuable source of these components in the food of forest animals.

Author Contributions: Conceptualization, W.Z. and B.W.; Data curation, W.Z. and B.W.; Formal analysis, W.Z., B.W. and G.N.; Funding acquisition, W.Z., B.W. and G.N.; Investigation, W.Z.; Methodology, W.Z. and B.W.; Project administration, G.N.; Resources, W.Z. and G.N.; Software, B.W. and G.N.; Supervision, W.Z.; Validation, B.W.; Visualization, B.W. and G.N.; Writing—original draft, W.Z., B.W. and G.N.; Writing—review and editing, W.Z., B.W. and G.N. All authors have read and agreed to the published version of the manuscript.

Funding: This research received no external funding.

Acknowledgments: Special thanks to Stanisław Kozłowski and Piotr Goliński for inspiration to the research and for their support and assistance during the experiments.

Conflicts of Interest: The authors declare no conflict of interest.

\section{References}

1. Frey, L. Trawy niezwyciężone (wybrane zagadnienia z historii, taksonomii i biologii Poaceae). Grassld. Sci. Pol. 2000, 3, 9-17.

2. Kozłowski, S.; Goliński, P.; Golińska, B. Pozapaszowa funkcja traw. Grassld. Sci. Pol. 2000, 3, 79-94.

3. Kozłowski, S.; Swędrzyński, A. Traw śródleśnych piękno. Mater. Ośrodka Kult. Leśnej 2009, 8, 47-58.

4. Zhao, Y.; Liu, Z.; Wu, J. Grassland ecosystem services: A systematic review of research advances and future directions. Landsc. Ecol. 2020, 35, 793-814. [CrossRef]

5. Ferchmin, M. Szata roślinna wydm i bagien Puszczy Kampinowskiej. W: Z Mazowsza na Polesie i Wileńszczyzną. Zróżnicowanie i ochrona szaty roślinnej pogranicza Europy Środkowej i Północno-Wschodniej. Pod red. A. Obidzińskiego. In Monografia Sesji Terenowej LV Zjazdu Polskiego Towarzystwa Botanicznego Planta In Vivo, In Vitro et In Silico; PTB: Warszawa, Poland, 2010; pp. 57-66.

6. Zając, A.; Zając, M. Atlas rozmieszczenia roślin naczyniowych w Polsce; Nakład Pracowni Chorologii Komputerowej Instytutu Botaniki UJ: Kraków, Poland, 2001.

7. Tsvelev, N.N. Zlaki SSSR; Nauka: Leningrad, Russia, 1976.

8. Tutin, T.G.; Heywood, V.H.; Burges, N.A.; Moore, D.M.; Valentine, D.H.; Walters, S.M.; Webb, D.A. Flora Europea; Cambridge University Press: Cambridge, UK, 1974; Volume 5.

9. Dżugan, M. Czynniki wpływające na stabilność zielonych barwników roślin. Zesz. Nauk. PTG 2006, 7, $27-33$.

10. Rajalakshmi, K.; Banu, N. Extraction and estimation of chlorophyll from medicinal plants. Intern. J. Sci. Res. 2015, 4, 209-212.

11. Falkowski, M.; Olszewska, L.; Kukułka, I.; Kozłowski, S. Reakcja odmian życicy trwałej (Lolium perenne L.) na azot i wodę. Biul. Oceny Odmian 1986, 16, 103-112.

12. Zielewicz, W.; Kozłowski, S. Żywotność Sorghum saccharatum (L.) Pers. w aspekcie możliwości jego uprawy w Polsce. Fragm. Flor. Geobot. Polon. 2007, 9, 173-181.

13. Gregorczyk, A.; Raczyńska, A. Badania korelacji między metodą Arnona a pomiarami zawartości chlorofilu za pomocą chlorofilometru. Zesz. Nauk. AR Szczec. Rol. 1997, 68, 119-123.

14. Falkowski, M.; Kukułka, I. Zawartość chlorofilu jako wskaźnika biologicznych właściwości roślin łąkowych. Roczn. Nauk. Rol. Seria F 1977, 79, 87-104. 
15. Kozłowski, S.; Goliński, P.; Golińska, B. Barwniki chlorofilowe jako wskaźniki wartości użytkowej gatunków i odmian traw. Zesz. Probl. Post. Nauk. Rol. 2001, 474, 215-223.

16. Goliński, P. Efektywność nawożenia azotem w produkcji nasion Lolium perenne L. Rozpr. Nauk. Akad. Rol. Pozn. 2001, 321, 20-29.

17. Selzer, L.J.; Busso, C.A. Pigments and photosynthesis of understory grasses: Light irradiance and soil moisture effects. Russ. J. Plant Phys. 2016, 63, 224-234. [CrossRef]

18. Golińska, B. Chlorofil jako wskaźnik azotowej kondycji Poa pratensis (Poaceae) w warunkach wielokrotnej defoliacji jej runi. Fragm. Flor. Geobot. Pol. 2007, 9, 137-145.

19. Gáborčik, N. Relationship between contents of chlorophyll $(\mathrm{a}+\mathrm{b})$ (SPAD values) and nitrogen of some temperate grasses. Photosynthetica 2003, 41, 285-287. [CrossRef]

20. Gáborčik, N. Koncentrácia minerálnych živin chlorofylu a+b (SPAD hodnoty) v listoch tokajskỳch odrôd viniča. Vinič Vino 2006, 3, 2-4.

21. Stahl, W.; Sies, H. Bioactivity and protective effects of natural carotenoids. Bioch. Bioph. Acta 2005, 1740, 101-107. [CrossRef]

22. Falkowski, M.; Kukułka, I. Zawartość karotenu jako cecha charakterystyczna roślin łąkowych. Roczn. Nauk. Roln. Seria F 1977, 79, 105-112.

23. Kozłowski, S.; Kukułka, I. Zróżnicowanie polskich odmian hodowlanych Lolium perenne pod względem barwników. Pr. Zakr. Nauk. Rol. PTPN 1996, 81, 103-111.

24. Olszewska, M. Wpływ stresu wodnego na intensywność fotosyntezy, zawartość chlorofilu i plonowanie Lolium perenne. Grassld. Sci. Pol. 2002, 5, 163-172.

25. Smith, J.H.C.; Benitez, A. Chlorophylls: Analysis in plant materials. In Moderne Methoden der Pflanzenanalyse, Band 4; Peach, K., Tracey, M.V., Eds.; Springer: Berlin/Heidelberg, Germany, 1955; pp. 142-196.

26. Berger, S. Metoda ilościowego oznaczania beta karotenu (Prowitamina A) i sumy karotenoidów w niektórych produktach roślinnych. Rocz. Państwowego Zakładu Hig. 1953, 4, 473-479.

27. Selyaninov, G.T. Methods of climate description to agricultural purposes. In World Climate and Agriculture Handbook; Selyaninov, G.T., Ed.; Gidrometeoizdat: Leningrad, Russia, 1937; pp. 5-27.

28. Skowera, B.; Puła, J. Skrajne warunki pluwiotermiczne w okresie wiosennym na obszarze Polski w latach 1971-2000. Acta Agroph. 2004, 3, 171-177.

29. Zielewicz, W.; Kozłowski, S. Występowanie barwników chlorofilowych i karotenowych w trawach leśnych. Grassld. Sci. Pol. 2011, 14, 161-170.

30. Kozłowski, S.; Swędrzyński, A. Zmienność występowania barwników chlorofilowych i karotenoidowych w odmianach hodowlanych Lolium perenne (Poaceae). Fragm. Flor. Geobot. Pol. 2007, 9, 163-171.

31. Noziere, P.; Graulet, B.; Lucas, A.; Martin, B.; Grolier, P.; Doreau, M. Carotenoids for ruminants: From forages to dairy products. Anim. Feed Sci. Technol. 2006, 131, 418-450. [CrossRef]

32. Strusińska, D.; Antoszkiewicz, Z.; Kaliniewicz, J. The concentrations of $\beta$-carotene, vitamin A and vitamin $\mathrm{E}$ in bovine milk in regard to the feeding season and the share of concentrate in the feed ration. Rocz. Nauk. Pol. Tow. Zoot. 2010, 6, 213-220.

33. Noziere, P.; Groiler, P.; Durand, D.; Ferlay, A.; Pradel, P.; Martin, B. Variations in carotenoids, fatsoluble micronutrients and color in cows plasma and milk following changes in forage and feeding level. J. Dairy Sci. 2006, 89, 2634-2648. [CrossRef]

34. Chauveau-Duriot, B.; Thomas, D.; Portelli, J.; Doreau, M. Carotenoids content in forages: Variation during conservation. Renc. Rech. Rumin. 2005, 12, 117.

35. Prache, S.; Priolo, A.; Groiler, P. Persistence of carotenoid pigments in the blood of concentrate-finished grazing sheep: Its significance for traceability of grass-feeding. J. Anim. Sci. 2003, 81, 360-367. [CrossRef]

36. Reynoso, C.R.; Mora, O.; Nieves, V.; Shimada, A.; De Mejia, E.G. Beta-carotene and lutein in forage and bovine adipose tissue in two tropical regions of Mexico. Anim. Feed Sci. Technol. 2004, 113, 183-190. [CrossRef]

37. Williams, P.E.V.; Ballet, N.; Robert, J.C. A review of the provision of vitamins for ruminants. In Proceedings of the Preconference Symp. of the Cornell Nutrition Conference 1998. Provision of Vitamins and Amino Acids for Ruminants; Rhone Poulen Animal Nutrition: Anthony, France, 1998; pp. 7-37.

38. Kalač, P. The effects of silage feeding on some sensory and heath attributes of cow's milk. Rev. Food Chem. 2011, 125, 307-317. [CrossRef] 
39. Krzyżewski, J.; Strzałkowska, N.; Bagnicka, E.; Jóźwik, A.; Horbańczuk, J.O. Wpływ antyoksydantów zawartych w tłuszczu pasz objętościowych na jakość mleka krów. Żywność Nauka Technol. Jakość 2012, 3, $35-45$.

40. Grzebisz, W.; Przygocka-Cyna, K.; Szczepaniak, W.; Diatta, J.B.; Potarzycki, J. Magnesium as a nutritional tool of nitrogen efficient management-plant production and environment. J. Elementol. 2010, 15, 771-788. [CrossRef]

41. Mazur, T.; Rogalski, L. Wpływ nawożenia mineralnego na cechy morfologiczne łodyg i zawartość barwników w liściach ziemniaków. Acta Agrobot. 1977, 30, 71-83. [CrossRef]

42. Tomaszewski, B.; Majtkowska, G.; Majtkowski, W. Zawartość chlorofilu u wybranych ekotypów i odmian prosa rózgowatego (Panicum virgatum L.) w warunkach zróżnicowanego nawożenia. Biul. Inst. Hod. Akl. Roś. 2016, 280, 71-77.

43. Higgins, S.; Morrison, S.; Watson, C.J. Effect of annual applications of pelletised dolomitic lime on soil chemical properties and grass productivity. Soil Use Manag. 2012, 28, 62-69. [CrossRef]

44. Suttle, N.F. Mineral nutrition of Livestock. 2010. Available online: www.carbo.org (accessed on 4 June 2020).

45. Kavanová, M.; Lattanzini, F.A.; Grimoldi, A.A.; Schnyder, H. Phosphorus deficiency decreases cell division and elongation in grass leaves. Plant Phys. 2006, 41, 766-775. [CrossRef] [PubMed]

46. Duru, M.; Ducrocq, H. A nitrogen and phosphorus herbage nutrient index as a tool for assessing the effect of $\mathrm{N}$ and P supply on the dry matter yield of permanent pastures. Nutr. Cycl. Agroecosyst. 1997, 47, 59-69. [CrossRef]

47. Shipley, B.; Almeida-Cortez, J. Interspecific consistency and intraspecific variability of specific leaf area with respect to irradiance and nutrient availability. Ecoscience 2003, 10, 74-79. [CrossRef]

48. Gommers, C.M.M.; Visser, E.J.W.; Onge, K.R.S.; Voesenek, L.A.C.J.; Ronald, P. Shade tolerance: When growing tall is not an option. Trends Plant Sci. 2013, 18, 1360-1385. [CrossRef]

49. Dai, Y.; Shen, Z.; Liu, Y.; Wang, L.; Hannaway, D.; Lu, H. Effects of shade treatments on the photosynthetic capacity, chlorophyll fluorescence, and chlorophyll content of Tetrastigma hemsleyanum Diels et Gilg. Environ. Exp. Bot. 2009, 65, 177-182. [CrossRef]

50. Dias-Filho, M.B. Photosynthetic light response of the $\mathrm{C}_{4}$ grasses Brachiaria brizantha and B. humidicola under shade. Sci. Agric. 2002, 59, 65-68. [CrossRef]

51. Ashraf, M.Y.; Azmi, A.R.; Khan, A.H.; Ala, S.A. Effect of water stress on total phenols, peroxidase activity and chlorophyll content in wheat. Acta Physiol. Plant. 1994, 16, 185-191.

52. Farooq, M.; Wahid, A.; Kobayashi, N.; Fujita, D.; Basra, S.M.A. Plant drought stress: Effects, mechanisms and management. Agron. Sustain. Dev. 2009, 29, 185-212. [CrossRef]

53. Sourour, A.; Afef, O.; Mounir, R.; Mongi, B.Y.A. Morphological, physiological, biochemical and molecular plant responses to water deficit stress. Intern. J. Eng. Sci. 2017, 6, 1-4. [CrossRef]

54. Kalaji, H.M.; Żebrowski, M. Intensywność fotosyntezy jedno- i dwuliściennych roślin $\mathrm{C}_{3}$ i $\mathrm{C}_{4}$ w różnych warunkach środowiska. Zesz. Probl. Post. Nauk. Rol. 2004, 496, 133-142.

55. Olszewska, M.; Grzegorczyk, S.; Olszewski, J.; Bałuch-Małecka, A. Porównanie reakcji wybranych gatunków traw na stres wodny. Grassld. Sci. Pol. 2010,13, 127-136.

56. Falkowski, M. Trawy Polskie; Praca zbiorowa pod redakcją M. Falkowskiego; Państwowe Wydawnictwo Rolnicze i Leśne: Warszawa, Poland, 1982.

57. Falkowski, M.; Kukułka, I.; Kozłowski, S. Właściwości chemiczne roślin łąkowych; Wydawnictwo Akademii Rolniczej im. Augusta Cieszkowskiego w Poznaniu: Poznań, Poland, 2000; pp. 59-84.

Publisher's Note: MDPI stays neutral with regard to jurisdictional claims in published maps and institutional affiliations.

(C) 2020 by the authors. Licensee MDPI, Basel, Switzerland. This article is an open access article distributed under the terms and conditions of the Creative Commons Attribution (CC BY) license (http://creativecommons.org/licenses/by/4.0/). 